UDC 342.7. DOI https://doi.org/10.32841/2307-1745.2021.51.33

Ignatieva A. I., orcid.org/0000-0002-3446-4036 Candidate of Pedagogical Sciences, Lecturer at the Department of General Military Disciplines Military Law Institute of Yaroslav Mudryi National Law University

\title{
THE SYSTEM OF MILITARY LAW OF UKRAINE AND GREAT BRITAIN IN MODERN INTERNATIONAL LAW
}

Summary. The article researched the issues of the military justice system in modern international law. The purpose of the article is to analyze the current state of military justice in Ukraine and Great Britain, make proposals for the creation of an integrated system of military justice of Ukraine. The paper is executed by applying the general research and special methods of scientific cognition. The article analyses the basic doctrinal approaches of military justice is one of the elements of ensuring the military security of the state. The military security of the state is seen as the protection of state sovereignty, territorial integrity and democratic constitutional order.Compared to Ukraine, in the United Kingdom, most military offenses against the service law are dealt with by commanders through a summary hearing. The commander may consider the offense by a summary hearing if the offense is minor and the accused has the rank of commander of the Navy, lieutenant colonel of the army or the Royal Marines or below his rank, or commander of the wing in the army.

The difference applied in the army and the Royal Air Force between district military and municipal military courts (with more limited full-scale remote preparations of military district courts than in other military aircraft) was also identified.

A military court may hear any breach of the law of service, including all contractual procedures under the laws of England and Wales. The procedure in this similar procedure is the Royal Court in England and Wales. The court is presided over by a lawyer, and there is a panel (similar to a jury) of three seeds (depending on the seriousness of the crimes) of officers.

In support of the claim for autonomy of military law, there is a strong argument that the ethos, tasks and responsibilities of the armed forces are unique, and therefore the legal system must reflect this. Whether the core values defined by the services, which include moral integrity, loyalty, honesty, mutual support, self-discipline, and group identification (as opposed to the pursuit of individual superiority), are the only reserve of members of the Armed Forces debatable. Indeed, the uniqueness of the claimed "unlimited liability" of personnel services and the degree of self-sacrifice that military service may require in certain circumstances.

The last reflection when we look at the detailed civil law rules regarding the Armed Forces is that it may reassure military sociologists rather than lawyers who are assessing whether the military spirit is really destroyed by lawyers' violins and the cult of individualism. However, if this were indeed the case, it would certainly not be without irony that the recent rapid increase in the number of military lawyers has taken place, and may well continue, will be not only a consequence of the jurisdiction of military law but also a cause of it.

Key words: military justice, military prosecutor's offices, ensuring legality, military discipline, legal system, legal values, responsibility.
Problem statement. The effective functioning of public authorities is a prerequisite for the protection of the constitutional order, ensuring law and order, respect for human and civil rights and freedoms. The reliability of the protection of Ukraine's national interests largely depends on the coordinated activities of the military judiciary, which is the key to the stable development of society [1, p. 11-12].

Analysis of recent researches. Scientific aspects of the problems of military justice were studied by such scientists as: O. Baganets, P. Bogutsky, Y. Vynokurov, Y. Viitev, M. Govorukha, M. Golomsha, V. Gusarov, V. Davydenko, V. Dolezhan, T. Dunas, S. Yevdokimenko, O. Zarkhin, P. Karkach, M. Karpov, V. Karpuntsov, M. Kislitsyn, M. Kovalev, V. Kozachuk, O. Kozachuk, I. Kozyakov, M. Kosyuta, V. Kravchuk, O. Litvak, V. Maksimov, V. Malyarenko, I. Marochkin, A. Matios, O. Mikhailenko, M. Mychko, S. Podkopaev, A. Polozov, M. Rudenko, MM Rudenko, O. Savenkov, G. Sereda, O. Smirnov, E. Subotin, V. Sukhonos, M. Trofimov, M. Turkot, A. Chorny, M. Yakymchuk.

The purpose of the article is to analyze the current state of military justice in Ukraine and Great Britain, make proposals for the creation of an integrated system of military justice of Ukraine.

Presenting main material. Military law, the body of law concerned with the maintenance of discipline in the armed forces. Every state requires a code of laws and regulations for the raising, maintenance, and administration of its armed forces, all of which may be considered the field of military law. The term, however, is generally confined to disciplinary military law as defined above, that part of the code that aims at and sanctions the maintenance of discipline in the armed forces. In the past this was also known by the name of martial law, a term that now has the meaning of military enforcement of order upon a civil population either in occupied territory or in time of disorder.

Members of armed forces do not cease under modern conditions to have duties as citizens and as human beings. All systems of military law thus must aim to ensure that the soldier is in no way enabled to escape the obligations of his country's ordinary law or of international law as recognized in various conventions.

Over the past few years it has become increasingly clear that United Kingdom military law has ceased to be the narrow preserve of military lawyers and of a handful of civilian lawyers who occasionally appeared before courts martial. Thus challenges before the European Court of Human Rights (ECHR) in respect of the perceived lack of independence of courts martial (which eventually resulted in remedial legislation); superior court sentencing guide- 
lines for courts martial; the criminal consequences of the use by service personnel of lethal force.

One of the most controversial problems of the national legal system is the ongoing discussion around the system of military justice, the need for such a system, organizational features, institutional design. In such discussions, historical arguments about military courts, about the military justice of the Ukrainian state of the Cossack era, about the existence of a system of military justice in other periods of Ukraine's history are for some reason not convincing. Many people pay attention, obviously, to the long historical period of the absence of Ukrainian statehood, and therefore turn to European approaches in resolving these issues [5].

Military offences are defined under various laws and, in particular, under the acts relating to each branch of the armed services. For example, as far as the Army is concerned, military offences are often known as "offences against the Army Act". In any event, the concept of a military offence in the British system encompasses both military offences, as they are generally understood, and disciplinary offences or breaches. Which category an offence falls into hinges on its gravity (minor or serious) and, in principle, a different procedure applies to each: minor offences are dealt with by means of a summary trial while serious ones go to a court martial. Minor offences seem to equate to what other legal systems call breaches of discipline while serious offences are on a par with military offences. Nevertheless, this distinction is not clear because whether a summary trial is applicable not only depends on the offence being of a minor nature but also on the rank of the accused (whether he or she is a soldier or non-commissioned officer) and whether or not the latter has elected trial by court martial. Some authors believe that the consequence of this type of system is the creation of two forms of military jurisdiction, one for disciplinary matters and another for criminal matters. Nevertheless, it may be misleading to view the British system by extrapolating from "continental" systems [4].

The main tasks of the Military Police are:

- prevention of commission, detection and cessation of crimes and other offenses in the Ministry of Defense, the Armed Forces, law enforcement agencies of special purpose (hereinafter - law enforcement agencies) and other military formations formed in accordance with the law within the powers granted;

- pre-trial investigation of crimes and criminal offenses related to military service committed by servicemen, as well as corruption crimes committed by employees and civil servants of the Ministry of Defense and the Armed Forces (hereinafter - employees);

- identification of the causes, preconditions and circumstances of crimes and other offenses committed by servicemen, employees, as well as other crimes committed in military units and military facilities;

- carrying out operative-search activity within the given powers;

- execution in cases provided by law of decisions on keeping servicemen on guard duty, in the rooms of temporarily detained, special chambers of health care institutions of the Ministry of Defense;

- ensuring the execution of criminal punishment in respect of servicemen who have been sentenced by a court to detention in a disciplinary battalion;

- participation in the cessation of illegal actions of civilians on the territories of military units, military educational institutions, institutions and organizations of the Ministry of Defense and the Armed Forces, military camps of the Ministry of Defense and the Armed Forces;
- ensuring law and order among servicemen, as well as employees during the performance of their official duties on the territory of military units, military towns, in public and other places, cessation of their commission of crimes and other offenses;

- conducting official investigations within the competence;

- protection of property of the Armed Forces from theft and other criminal encroachments;

- ensuring road safety of military vehicles of the Armed Forces, law enforcement agencies and other military formations;

- participation in garrison events;

- protection of the rights and freedoms of servicemen from unlawful encroachments;

- taking special security measures to protect servicemen and employees of the Military Police in the event of a real threat to their lives and health, housing and property in connection with their official activities, as well as to protect their close relatives;

- participation in the prevention of subversive acts and terrorist crimes on the territory of military units;

- ensuring control over compliance with the established access regime to the administrative and technical territories of arsenals, bases and depots of the Armed Forces and compliance with certain requirements for the maintenance and storage of weapons, missiles, ammunition and explosives;

- search and detention of servicemen who left military units (places of service), including those who illegally seized weapons and pose a danger to others;

- search for firearms, ammunition or explosives stolen or lost in military units;

- ensuring law and order and military discipline in military units (subdivisions) of the Armed Forces, law enforcement agencies and other military formations sent to other states;

- interaction with internal affairs bodies, military commands of the Armed Forces, law enforcement agencies and other military formations, in order to perform the tasks and functions of the Military Police [4].

Consequently,the european state with a deep historical background to the development of democracy, which went through revolutionary events in the 17th century and built an exemplary legal system with the right to justice, which applies to all without exception.

The Rebellion Act not only provided for criminal penalties for crimes against military service, but also defined a certain procedure for dealing with such cases, which differed from the general procedure, but provided for the administration of justice by military judges with the participation of a military prosecutor. The provisions of British law have been improved since the adoption of the Rebellion Act in 1689, and the military justice system has been successful since the adoption of the Armed Forces Act in 2006.

In addition to certain powers of the command, military police units, the British military justice system provides for the activities of military (military field) courts, as well as the deployed Service of Prosecutors (Service Prosecuting Authority) with the status of servicemen. The jurisdiction of the British military courts extends to all servicemen, as well as to civilians who act in the interests of the Armed Forces or are support staff, in the case of committing not only war crimes but also general crimes. The rule of military justice is strictly enforced solely with respect for human rights, in the public interest and in the interests of the combat capability of the British Armed Forces, the level of which can be an example 
for many countries, including Ukraine. Ensuring the combat capability of the British Armed Forces is considered a common cause of all the people of the United Kingdom. The following provisions of the Law of Ukraine "On the Prosecutor's Office" should be considered as systematic and effective in ensuring the implementation of tasks and powers of the prosecutor's office in the field of defense:

1) determination of military prosecutor's offices by specialized prosecutor's offices, the subject of activity of which, in accordance with the functions and powers of the prosecutor's office, is exclusively the sphere of defense and activities of subjects subject to the legal regime of military service;

2) determining the place of specialized military prosecutor's offices in the prosecutor's office system in accordance with the provisions of Art. 7 of the Law of Ukraine "On the Prosecutor's Office";

3) the specialized military prosecutor's office is organizationally formed by all units provided by the Law of Ukraine "On the Prosecutor's Office", namely: the relevant subdivision of the General Prosecutor's Office of Ukraine (Office of the Prosecutor General); specialized military prosecutor's offices of regional (oblast) level; specialized military prosecutor's offices of local (district) level; at the same time, the structure of the specialized military prosecutor's office is based on the military-administrative division of the state and depends on the deployment of military units, institutions of the Armed Forces, and other military formations formed in accordance with the law;

4) the head of the specialized military prosecutor's office must be one of the deputy prosecutors general;

5) prosecutors, as well as investigators of the specialized military prosecutor's office, in addition to the relevant status defined by the Law of Ukraine "On the Prosecutor's Office", must have the status of servicemen, with features defined by the legislation on the prosecutor's office, including guarantees of prosecutors' independence;

6) regulations on military service in the specialized military prosecutor's office shall be approved by the President of Ukraine;

7) ensuring the activities of military prosecutor's offices is carried out at the expense of the budget of the Prosecutor's Office of Ukraine; the procedure for logistical and other support of military prosecutor's offices is determined by the Cabinet of Ministers of Ukraine [2].

So, Police functions in the UK.

In peacetime:

- ensuring the security of personnel, weapons, equipment and property of the Armed Forces both at military facilities and outside them;

- protection of public order in the part concerning servicemen and civilian personnel of the Armed Forces;

- patrolling military facilities;

- carrying out investigative and search activities on the territory of military facilities;

- detention and interrogation of suspects;

- inspection of military vehicles.

In wartime:

- radiation and chemical reconnaissance of the rear areas;

- protection and escort of prisoners of war;

- search and collection of retarded or those who have lost contact with troops, units and individual servicemen [4].

Conclusions. We noted, that the It should be noted that among the factors that determine the inefficiency of the national security system of Ukraine, the National Security Strategy of Ukraine focuses on the immaturity of the security and defense sector of Ukraine (hereinafter - the security and defense sector) as a single functional association managed from a single center; on institutional weakness, unprofessionalism, structural imbalance of security and defense sector bodies. Under such circumstances, the importance of the military justice system, which is centered on the military prosecutor's office, increases significantly.

While explanations for civilianisation might be attributed to the professional influence of military lawyers who perceived practical advantages for military discipline in adopting certain civilian criminal rules, or to a government (and departmental) ideology favouring a limited convergence of civil and military law, juridification was a different matter. Here one can identify not a proactive nor wholly consensual process of legal change, but one which, certainly in the initial stages, has been viewed by the armed forces with at best wariness and at worst hostility at the perceived prospect of military effectiveness being imperilled.

Lastly, the most salient feature of British military justice is that no clear distinction exists between criminal and disciplinary offences.

These issues all accentuate individual preferences. However military ethos has always been uncomfortable with, and (given a choice) will favour exemption from civilian laws which stress rights and not duties, and individual benefit.

\section{References:}

1. Gorbunov E.A. Self-organization of systems and forecasting of military-political and social aspects: textbook. way. Kyev : NikaCenter, 2015. P. 11-16.

2. On the Prosecutor's Office : Law of Ukraine of December 06, 1991 (date of update: January 01, 2021) No. 1934-XII / Verkhovna Rada of Ukraine. Bulletin of the Verkhovna Rada of Ukraine. 2015. № 2-3. Art. 12. URL: https: //zakon.rada.gov.ua/laws/show/1934-12 (access date: 04.04 .2021 ).

3. On the Armed Forces of Ukraine : Law of Ukraine of December 06, 1991 № 1934-XII-VR / Verkhovna Rada of Ukraine. Bulletin of the Verkhovna Rada of Ukraine. 1991. № 9. Art. 4. URL: https:// zakon.rada.gov.ua/laws/show/1934-12 (access date: 04.04.2021).

4. Military Justice System. Ministry of Justice on GOV.UK - Her Majesty's Government. Archived from the original on May 12, 2008 and Section 362. URL: https://www.gov.uk/government/organisations/ ministry-of-justice; http://www.army.mod.uk/militarylaw.

5. Youth Justice and Criminal Evidence Act (1999) whose relevant provisions have now been extended to courts martial by Sched 7, part 5 to the Armed Forces Act, 2001. URL: https://www.legislation.gov.uk/ ukpga/1999/23/schedules.

Ігнатьсва А. І. Система військового права України та Великобританії в сучасному міжнародному праві

Анотація. У статті досліджено питання системи військової юстиції України й Великобританії в сучасному міжнародному праві. Метою статті $\epsilon$ аналіз сучасного стану військової юстиції України й Великобританії та внесення пропозицій щодо створення цілісної системи військового судочинства України. Стаття виконана із застосуванням загальних досліджень і спеціальних методів наукового пізнання.

Зазначено, що військове правосуддя є одним з елементів забезпечення військової безпеки держави. Військова безпека держави розглядається як захист державного суверенітету, територіальної цілісності й демократичного конституційного ладу. У порівнянні з Україною у Вели- 
кобританії більшість військових правопорушень проти закону про службу розглядаються командирами шляхом короткого слухання. Командир може розглянути правопорушення шляхом короткого слухання, якщо правопорушення незначне, а обвинувачений має звання командира Військово-морських сил, підполковника армії або Королівської морської піхоти або нижче його звання, або командира крила в армії.

Також виявлено різницю, застосовану в армії та Королівських Військово-повітряних сил між окружними військовими й муніципальними військовими судами (з більш обмеженою повномасштабною дистанційною підготовкою військових окружних судів, ніж в інших військових літаках).

Згідно із законодавством Англії та Уельсу Військовий суд може розглянути будь-яке порушення закону про службу, включаючи всі договірні процедури. Подібна процедура - Королівський суд в Англії та Уельсі. Суд очолює адвокат, і існує колегія (подібно до складу присяжних) із трьох насінин (залежно від тяжкості злочинів) офіцерів.

На підтримку вимоги про автономію військового права існує вагомий аргумент про те, що етос, завдання та обов'язки збройних сил унікальні, тому правова система повинна це відбивати. Чи є основні цінності, визначені службами, що містять моральну цілісність, лояльність, чесність, взаємопідтримку, самодисципліну й ідентифікацію групи (на відміну від досягнення індивідуальної переваги), єдиним резервом для членів Збройних Сил - спірно. Дійсно, унікальність заявленої «необмеженої відповідальності» кадрових служб - ступінь самопожертви, якої може вимагати військова служба за певних обставин.

Останнє відбиття, коли ми розглядаємо докладні норми цивільного законодавства щодо Збройних Сил, полягає в тому, що це може заспокоїти військових соціологів, а не юристів, які оцінюють, чи справді військовий дух знищений адвокатською скрипкою та культом індивідуалізму. Однак, якби це справді було так, безумовно, не без іронії було б, що нещодавнє швидке збільшення кількості військових юристів $є$ та цілком може продовжуватися не лише як наслідок юрисдикції військового законодавства, але і як його причина.

Ключові слова: військова юстиція, військові прокуратури, забезпечення законності, військова дисципліна, система права, правові цінності, відповідальність. 